\title{
Philippe Carrard*
}

\section{Mapped stories: Cartography, history, and the representation of time in space}

https://doi.org/10.1515/fns-2018-0022

\begin{abstract}
As novels can be mapped, maps in return can be shown to have a narrative dimension. Maps referring to historical events, for instance those of the invasion of the USSR in June 1941, obviously tell a story. Recounted through graphic means, that story has specific aspects in the areas of order, duration, frequency, authorship, and perspective. Yet, similar in this respect to the descriptions that historians provide, narrative maps are neither neutral, nor whole. Grounded in selection, they necessarily develop an argument, are incomplete, and rely on symbols that are both conventional and arbitrary.
\end{abstract}

Keywords: map, narrative space, spatialize, cartography, perspective

Most studies devoted to the relations between geography and narrative theory have focused on the way stories can be spatialized. ${ }^{*}$ Charting such things as the plots of Jane Austen's novels (Moretti 1998: 19) and characters' journeys in Atom Egoyan's film Ararat (Caquard \& Fiset 2014), they have shown, as Marie-Laure Ryan (2016: 65) puts it, how stories can be told "with maps." Yet, Ryan observes, another, more problematic issue is to determine whether stories can be told "through maps." Using as examples maps of raft trips down the Colorado River, of Napoleon's Russian campaign, and of the siege of Geneva by the troops of the Duke of Savoy, Ryan answers in the affirmative. Graphs of this type, she argues, confirm that stories can indeed be told through visual means, even though such means - in the area of time - cannot provide as many specifics as language and film.

My purpose, extending Ryan's inquiry, is to examine how events can be represented through maps. Unlike scholars such as Moretti, Caquard, and Fiset, I

\footnotetext{
* I want to thank the Orion Publishing Group and Oxford University Press for giving me permission to reproduce maps included in their Atlases of World War Two (see pp. 24 and 25); geographers Frank Magilligan and Mona Monosh for vetting my argument; Irene Kacandes and Gerald Prince for encouraging me to pursue this line of inquiry and offering helpful suggestions.
}

*Corresponding author: Philippe Carrard, University of Vermont and Dartmouth College, E-Mail: Philippe.carrard@dartmouth.edu 
thus won't seek to chart the spatial component of narrative representations. Instead, or rather conversely, I will look at the way spatial representations may have a narrative component, and how this component is inscribed. Furthermore, just as Ryan focuses on maps of Napoleon's campaign and the siege of Geneva, I will analyze maps that represent actual, not fictional, events. My corpus will consist of two maps related to the German invasion of the USSR in June 1941 included in atlases of World War II: a descriptive map, showing the military balance at the German-Russian border in spring 1941 (Young 1999: 85); and a narrative map, accounting for the first phase of the invasion, from June 22 to early October (Story 2006: 35). I selected these specific maps because prior research made me familiar with the Eastern Front (Carrard 2010), and also because they offered convincing examples of the way graphs can both depict a situation and recount the events that ensue of it. While the two books I am using are labelled "atlases," they are not made up of graphs exclusively. Both come with accompanying texts (Young's also includes photographs), displayed on the pages facing the maps in Story's work, on the same or the opposite pages in Young's. I won't look at this disposition in more detail, even though it raises the interesting issues of knowing whether the text is completing the map or the map illustrating the text, and whether readers proceed from the map to the text, from the text to the map, or go back and forth between the two.

\section{Narrating space}

By selecting maps that represent historical events and situations, and maps of the traditional type, I have of course made my task easier. Historiographic discourse has in most (all?) cases a spatial component, because the political, military, economic, and cultural phenomena that it describes must be situated in space as well as in time. Whereas space, in fiction, can be "radically minimized without any obvious loss in 'narrativehood"' (Buchholz \& Jahn 2005: 551), it is difficult to envision historiographic studies that would not depict the environment in which the events that they report are occurring.

While wars necessarily take place in specific locations, space is not always the subject of contention that has brought them about. The campaigns of the French Revolution, for example, were mostly ideological; they involved political regime change and/or continuation more than territorial gains. The war on the Eastern Front, however, was primarily about space - a concept that especially in this context must be historicized. In 1941, "space" for the Nazis was synonymous with Lebensraum; it referred to the areas that Germany, having supposedly become too small given the size of its population, had to conquer in order to 
ensure its survival. These areas, according to the different versions of Generalplan Ost (as described most recently in Ingrao 2016), included the western part of the USSR up to the Ural Mountains, or at least to the Volga. This section of the country was to be occupied and colonized, the local populations being enslaved, displaced, or even killed when there would be no use for them.

The main aspects of the war on the Eastern Front have been detailed in numerous books (e.g., Müller and Ueberschär 2009) and this is not the place to rehearse them once again. From the standpoint of literary theory, it will suffice to point out that the situations and events described in maps 1 and 2 involve at least two narrative topoi: border crossing and invasion, terms that here must be taken not metaphorically, as is often the case in fiction (Krah 1999), but literally. Indeed, the Germans crossed the Russian border on 22 June 1941, and this crossing was violent and extended over a wide territory. Maps 1 and 2 give an idea of the size of the armed forces and the scope of the invasion, showing the many divisions included in Army Group North, Army Group Centre, and Army Group South waiting behind the border, then heading respectively towards Leningrad, Moscow, and the Ukraine. Still from the standpoint of literary theory, Maps 1 and 2 can also be regarded as representing what Mikhail Bakhtin (1981: 278) calls “chronotopes": time-space complexes, involving in these instances the periods September 1939September 1941, when Germany and the USSR, bound by the non-aggression pact they had signed in August 1939, were merely facing each other, and June 22, 1941early October 1941, when German troops had in a short time occupied part of western Russia, coming very close to Moscow.

I will return later to the symbols used in the two maps, but the narrative structure of Map 2 is made immediately obvious by the purple and green lines that the legend identifies as "front line, June 22" and "front line, early October," as well as by the curving-line arrows showing the advance of the German armies between these two dates. Map 2 thus definitely qualifies as a narrative, whether we define the term, with Gerald Prince (2012: 25), as "the logically consistent representation of at least two asynchronous events, or a state and an event, that do not presuppose or imply each other," or, with James Phelan (2007: 203), as "somebody telling somebody else on some occasion or for some purpose that something happened." This map does indeed tell that "something happened," while Map 1, in Prince's terminology, can be viewed as the "state" that preceded the "event," in this instance, the invasion of June 22.

While Map 2 has a narrative structure, one could ask whether that structure is endowed with "narrativity." More precisely, one could ask whether the way it represents the plot "border crossing and invasion" involves - to draw on Meir Sternberg's (1978) well-known categories - elements of suspense, curiosity, and surprise. Prince's (2008) distinction between "narrativehood" and "narrative- 
ness" is useful here. Indeed, although Map 2 possesses the distinctive features of a narrative (narrativehood), it probably lacks narrativeness: the information that it provides is devoid of the "tension" in which narratologists like Raphaël Baroni (2007) see the defining attribute of a "good," well-formed plot. Yet Map 2 is also part of an atlas of World War II, and thus one moment in a larger story. As such, it implicitly poses the question: what will happen next? That question is answered through the next five maps, which describe respectively the drive on Moscow, the Caucasus and Stalingrad campaigns, the Battle of Kursk, and finally the Soviets' move west (Story 2006: 37, 39, 41, 43, 45). Map 1 poses a similar question, namely: when will the actual fighting begin? It is answered on the next map (Young 1999: 87), which covers by and large the same period and territory as Map 2 does, but uses different graphic conventions. Narrativeness, of course, is a matter of degree (Prince 2005: 387), as some narratives offer more "tension" than others. Both Story's and Young's atlases are - to return to Sternberg's categories - grounded in "curiosity" more than they are in "suspense." Indeed, they posit readers who, while they cannot be unaware of how the war ended (the Allies "won", etc.), may still be anxious to establish where some specific events took place, or to acquire a more general knowledge of both the temporal and spatial dimensions of the conflict.

\section{Spacing time}

If Map 2 can be counted as a narrative because it reports that "something happened," what are its characteristics in the area that is most fundamental for storytelling, namely, time? I will now look at the ways it answers this question, focusing on the time-related domains of order, duration, and frequency.

As far as order is concerned, Map 2 falls under what Genette (1980: 217) calls "subsequent narrating": it reports past events, in this instance, events that occurred on the Eastern Front between late June and early October 1941. Yet that story is complex. The plot "invasion" that unfolds in Map 2 is in fact of the multiplot type, its three main lines corresponding to the routes of the three army groups. Map 2, in other words, consists of “parallel narratives” (O’Neil 2005: 368), a structure that is frequent in historiography, though obviously it is not actualized in the same way in a text and in a map. Whereas historians must proceed in linear fashion, in the case of the invasion of the USSR account consecutively for the concurrent activities of the three army groups, cartographers can provide (and readers benefit from) an immediate overview of the operations. The same thing, by the way, could be said of Map 1, which contributes an instant picture of the involved forces. In both cases, of course, readers will at some point introduce time 
in their viewing. Their eyes, as the geographer Gilles Plasky (2017: 60) puts it, will "follow a trajectory, move and stop at certain places," halting for instance at the proper names identified on the maps, or moving from the symbols to their deciphering in the legend that comes with the graph.

In the area of duration, Map 2 can be described as a "summary" (Genette 1980: 95), that is, as the highly digested representation of multifaceted events that occurred over a more or less specific lapse of time. Using a spatial metaphor to describe what he calls the "relationship between the time of the map and the time of the world," Wood (2010: 95) distinguishes between degrees of "thinness" and "thickness." Map 2, in Wood's terminology, would thus be "thinner" than the map showing the drive on Moscow (Story 2010: 37), because it covers about three months whereas the map of the drive to Moscow extends to about seven. To account for that same phenomena, narratologists predictably prefer a spatiotemporal metaphor: they speak of the "speed" of a text (Genette 1980: 86), that is, of the relations between the duration of an episode in terms of minutes, hours, days, etc. (to the extent that it can be established) and the number of words, lines, or pages that are devoted to it. The procedure is applicable to maps. Relying on the scale supplied at the right bottom of Map $2(1 \mathrm{~cm} .=100$ miles [= $161 \mathrm{~km}])$ and provided with a tape measure, we can establish that the advance of Army Group Center from June 22 to early October (14 weeks) stretches over five centimeters, which means that the speed of the map is approximatively $0,357 \mathrm{~cm}$. a week. Of course, map speed should not be confused with the actual speed of the German troops. Narrative maps, as Ryan (2016: 69) has argued, cannot represent the "abrupt changes of state" that punctuate the "processes" they account for, in this instance, the varying paces at which Army Group Center advanced into Russian territory.

What narratologists call "frequency" poses fewer problems of calculation. Map 2 is indeed a "singulative narrative" (Genette 1980: 114), as it tells one time what happened one time. This, let us note, is not always the case in narrative maps. Wood and Fels (2008: 73), for example, include maps of the paths of the 2004 North Atlantic storms that constitute "iterative narratives" (Genette 1980: 116): they tell one time what happened several times, which evidently doesn't imply that the paths were always exactly the same, nor that the storms always travelled at precisely the same speed. In the atlas I am using (Story 2006: 49), the map titled "Strategic bombing" can be regarded as telling a repeated story: it does not focus on single events but shows the places in Germany that British and American bombers would strike, as well as - represented by two lines - the routes that they would take on the way to their targets. Neither Young's nor Story's atlas actualizes the last model that narratologists (Genette 1980: 116) have identified: "repeating narrative": the structure that consists of telling several times what 
happened one time. They do not, for example, juxtapose maps using different scales, or drawn from contrasting perspectives, to offer alternative versions of the early stage of the invasion. That lack could of course be filled with an atlas that would offer several takes on the events of June-October 1941 - an atlas that of course would raise the basic issue of knowing whether the "same" events actually remain the same when they are represented in different ways.

\section{Authorship, or who is drawing?}

Author and narrator, according to theorists of narrative discourse (e.g., Cohn 1999: 123-124), must be distinguished in fiction, whereas they are the same "person," or at least exercise the same function, in historiography. Does this pair have an equivalent in cartography? To begin with, do maps have authors whose names are plainly displayed, as the name of the author is displayed on the cover and title page of most historical studies? In atlases, the identification of the cartographer seems to depend on the policies of the publishing house. On their title pages, Cassell's Atlas of the Second World War gives equal typographical weight to the items "Edited by Brigadier Peter Young" and "Cartography by Richard Natkiel," whereas Oxford's Concise historical atlas of World War Two only provides the name "Ronald Story" and makes no mention of a cartographer. Story himself (2006: 5), in his acknowledgments, thanks "Elyse Dubin, director of editing, design, and production... and Annika Sarin, designer.” Does this mean that Sarin must be regarded as the "author" of the maps? If she was under Dubin's supervision, what was the latter's involvement? Furthermore, and this question applies to both atlases, what were the constraints imposed by the publishers over their cartographers in domains such as the size of the maps, their scale, and the range of colors and symbols they would be able to use? Because I do not have any information about the way the maps in Story's and Young's atlases were actually produced, I will use "Natkiel” and "Sarin" as shortcuts to designate the author standing behind the cartographer and assume that the former endorses what the latter is designing. The possibility of a play (in both senses of the word) between the two would indeed severely jeopardize cartographic communication, as a similar play between author and narrator would endanger the credibility of historiographic discourse.

As author, Wood (1993: 70) has argued in his critical examination of the mapping process, the cartographer must "disappear," because it is only to the extent that he/she "escapes notice" that the world he/she designs can be "taken for the world." In the graphs in my corpus, the function of anchoring the events June-October 1941 in a way that "escapes notice" is fulfilled by what semioticians 
of graphics (Bertin 2011: 308) call a "base map": the "set of known reference points which are necessary and sufficient for situating the as yet unknown elements of the new information being mapped." The "known references" that make up Natkiel's and Sarin's base maps include topological and political entities; they refer to rivers, seas, marshes, and mountain ranges, as well as to borders, countries, and cities. In other words, they refer to "what is unquestionably there," or at least, in the case of borders, to "what was unquestionably there" at the time of the invasion.

While Wood examines how maps aim to be "taken for the world," he also insists that they in fact are "arguments." Mapmaking, for him, is "a rhetorical exercise" (Wood 2010: 43) whose goal is always to serve special interests. Wood's examples are maps of election returns in the United States, whose "argument" for him consists in overstating the strength of the Republican Party. In Natkiel's and Sarin's maps, the argument can be found at the level of both the linguistic and the symbolic codes on which they rely. Their titles, in this respect, are already revealing. "The military balance on the Eastern Front" (Young 1999: 84) and "Barbarossa - The invasion of the U.S.S.R." (Story 2006: 34) emphasize the military aspects of the conflict. Providing viewing instructions, they tell readers to focus on the size of the forces involved (Map 1), then on the movements of the three army groups (Map 2). As for the word "invasion," it assigns responsibilities; in line with the commonly accepted view of the initial phase of the conflict, it makes Germany into the offender. The same argument is developed on the level of the graphic code. That code is heavily iconic in Map 1, where each infantry division is represented by a soldier, each panzer division by a tank. It is more symbolic in Map 2, where the advance of the German armies and the few Russian counter-attacks are rendered with respectively black and brown curving-line arrows. Arrows, to be sure, are highly conventional signs frequently used in what cartographers (Monmonier 1993: 190) call "flow maps": maps that describe not just military operations, but such phenomena as migrations and international trade. Still, arrows are also weapons, and while they show routes in Map 2, they also connote speed and the possibility of physical damage. In both maps, therefore, linguistic and symbolic codes combine to provide an argument and inscribe the intervention of the cartographer. That intervention, to be sure, is likely to "escape notice," because it confirms the version of the events that most historians (beginning with Story on the page facing Map 2) have provided: the Germans were the aggressors; taking advantage of Russian disorganization, they first moved at fast pace; but they soon had to slow down because of increasing Russian resistance, equipment breakdown, and bad weather. While history, according to Walter Benjamin's (1969: 256) well-known thesis, is always "written by the victors," I am not aware of any account of the beginning of the war on the Eastern 
Front that would provide a legitimate alternative version. The Nazi thesis according to which the attack was a "preventive strike" has been consistently disproved, and - as far as mapping is concerned - I don't know of any atlas that would show that Maps 1 and 2 do not offer correct information, if not the correct information, on the size of the troops and their movements on the battlefield.

\section{Perspectives}

While cartographers, according to Wood, cannot avoid taking sides and developing arguments, they also - on a more basic level - must organize their graphs from a position that at first is spatial. Commenting on the way issues of "point of view" are dealt with in the study of both fictional and factual discourses, philosophers (e.g., Jacques Derrida 1978) and postclassical narratologists (e.g., Alain Rabatel 1998) have argued that the categories to which structuralist analysis turns in this area are inadequate, because they consist mostly of space-related metaphors that do not account for the linguistic phenomena at work in written texts. Insofar as maps necessarily include a spatial component, terms that originally refer to space such as "angle," "scope," "frame," "prism," and "stance" should be appropriate to describe specific aspect of cartography; or, at least, they should be more appropriate than they are in the analysis of narratives whose medium is language.

Maps 1 and 2 as well as all other maps in Young's and Story's atlases are designed from the aerial perspective that is most common in cartography. This position is usually described as the "bird's-eye view," and it obviously could not have been that of a human observer. Indeed, Natkiel's map is a snapshot that no cameraman could have taken, and I do not know if satellites would now be able to provide such comprehensive and detailed information. As for Sarin's map, it covers space travelled over several months, involving a cartographer who ideally would have followed from above, and mapped as he/she went along, the progression of the three army groups. The geographer John Pickles (2004: 80) calls this privileged situation the "cartographic gaze," a situation that for him has several distinct characteristics. First, that gaze assumes an "observer epistemology" and a "Cartesian commitment to vision" as the source of " direct' information about the world." Prioritizing "mathematical forms of abstraction over other forms of abstraction," it also sees itself as a "technical-scientific practice of representing (mirroring) nature." In sum, it is "both the view from above, an elevated two-point perspective bird's-eye-view, and an all seeing eye that views everywhere at the same time" (80).

Insofar as cartographers see everywhere "at the same time," their position is not just spatially but also temporally privileged in relation to that of actors and 
observers. Arthur Danto (1985: 11) has argued that historians always speak in light of their "here and now," more precisely, in the context of "ulterior information" that allows them to "say things that witnesses and contemporaries could not have said," on the model of "the Thirty Years War began in 1618." Cartographers are in a similar position. Natkiel's tableau, for example, was obviously drawn on the basis of evidence that became available after June 1941. It is doubtful that the German and Russian high commands had a knowledge as specific as Natkiel's about the exact strength of the other side, and the millions of soldiers who were ready to attack the USSR or defend it, at any rate, could not have been aware of their respective numbers and positions. In like manner, Sarin's graph does not merely summarize the first three months of the invasion. Covering the operations in a comprehensive manner that clearly exceeds most actors' understanding of the events (again, one might ask to what extent the German and Russian high commands were informed of the situation on all fronts), it is also produced by someone who is conversant with both the "whole story" and the "whole history." In other words, it is designed by someone who knows what happened in the USSR between June 22 and early October, between early October and the end of the war, as well as - more importantly - between the end of the war and the moment of designing. Indeed, it is her retrospective perspective that allows Sarin to chart time the way she does, in this instance, to make early October into the moment that marks the end of the Germans' rapid advance into Soviet territory.

Designed from a privileged spatial and temporal perspective, the maps in my corpus also originate in a "place" that ensures their legitimacy. I borrow the concept of "place" (lieu) from Michel de Certeau (1988: 61-62), who uses it to refer to the academic and/or editorial institutions in which the historical enterprise is necessarily grounded. That place, according to Certeau, makes certain types of research "possible" because of "common situations and problems," while it makes others "impossible," excluding them from discourse by exercising a kind of “censorship." Certeau's point certainly applies to cartography. If we first ask what made Maps 1 and 2 "possible," it is clear that war in general and World War II in particular fall under the "common situations and problems" that both the academy and the publishing business are likely to find worth exploiting. As for Natkiel's and Story's atlases in particular, their authority is first inscribed in what Wood (2008: xvi), on the model of Genette's (1987) "paratext," calls the "paramap": everything that "surrounds and extends the map in order to present it." As part of the "editorial perimap," the title page in Young's atlas thus specifies that the author is a "brigadier," a rank that makes Young especially qualified to treat the subject of "war." Similarly, the blurbs on the back cover of Story's atlas inform prospective readers that the author is a professor of history in a well-known school (University of Massachussetts at Amherst), a published scholar, and a busy 
editor and coeditor. While Natkiel and Sarin are merely identified as designers and are not granted specific notices, the maps they draw certainly gain from the "symbolic capital" (Bourdieu 1994:161) that their editorial perimaps provide. Such gain is especially obvious in the case of Story's atlas. Indeed, even though it is unassumingly labelled as "concise," that atlas is published by Oxford, a "place" endowed with institutional authority - if there ever was one. References to "from where it is mapped," therefore, do not constitute superficial features that earnest readers may simply ignore. They in both Young's and Story's cases shape the reception of the works, grounding them in what might be called - after Philippe Lejeune's (1989) "autobiographical pact” - the cartographic contract: an implicit contract which stipulates that the cartographer has done research, sorted out the available evidence, and then - as autobiographers write to the best of their recollection - has mapped what he/she was assigned to map to the best of his/her knowledge and ability.

\section{Deconstructing the map}

I have, so far, examined how the maps in my corpus "work," how they produce a reliable representation of what things were like at the German-Russian border in Spring 1941 (Map 1) and of what happened on the Eastern Front during the first months of the conflict (Map 2). For the past thirty years, however, concurrently with the human and social sciences, cartography has questioned its very premises. "Deconstructing the map" is thus the title of a frequently quoted and discussed article by the geographer and map historian John Brian Harley, initially published in 1989 and reprinted in Harley's collection of essays The new nature of maps (2001). In this article, Harley (2001: 154) first describes what he calls the "scientific epistemology" of his discipline. According to that epistemology, "the objects in the world to be mapped are real"; they enjoy "an existence independent of the cartographer"; their reality can be expressed "in mathematical terms," thus producing "cartographic truth"; and that truth "can be independently verified." Against these claims, Harley (2001: 159) insists that maps are not "mirrors" of the world, but "constructions employing a conventional sign system"; that they must be viewed as "texts," and as such be subjected to a "much closer and deeper reading" than the practice has been in cartography (159); and that their "social and political dimensions" make them work in society as a "form of power knowledge" (164). That power is first "external”: it is "exerted on cartography” by such institutions as the state, the military, and the Church (165). But it is also "internal": creating a "spatial panopticon," cartographers manufacture a power "embedded in the map text” (165). Relying explicitly on Foucault, Harley endorses 
here the philosopher's view of power as coming "from everywhere," in this case, "from" the graphs that it has first contributed to fashion during the process of mapping (166).

For narrative theorists, Harley's comments on cartography call to mind Philippe Hamon's (1982) analysis of the codes of "realist discourse" and Hayden White's (1978) review of the literary strategies at work in "factual representation." As Hamon and White do in their own fields, Harley exposes contradictions, here between cartography's claim to provide a faithful "picture of the world" and the reliance on rhetoric that an examination of its "practices" reveals. We saw earlier how the two maps in my corpus are rhetorical insofar as they develop arguments how for instance they emphasize the military side of the conflict and designate Germany as the aggressor. But these maps, more fundamentally, are also rhetorical because they were designed according to conventions that make them metaphors, rather than representations, of the territory that they cover. To begin with, like all maps, they originate in a projection, which in this case has transformed the curved, three-dimensional surface of the Russian territory into a flat, two-dimensional plane. That plane has then been scaled, framed, and coded in a way that is as conventional as it is arbitrary. Seas in Map 2, for example, are all colored blue, while we may ask, as the geographer Denis Cosgrove (2008: 162) does about the representation of water in his discipline, why they need to be blue "rather than green or turquoise"; like many other options related to coding, that choice seems to be driven more by custom than by "scientific considerations." Arbitrariness is also very much in evidence in map 1 , though not because color selection follows the code, but rather because it strangely goes against it. Indeed, the icons that represent the German and Russian troops are colored respectively red and black, while "red" is conventionally associated with communism and black was the color of the uniforms of the SS divisions, if not of the outfits of the whole German army. Though in different ways, therefore, Maps 1 and 2 do not represent things "the way they are," a diagnostic that Mark Monmonier applies to all maps in a book programmatically titled How to lie with maps. Such lying, according to Monmonier (1999: 1), is "essential" to provide "a useful and truthful picture" of the territory to be mapped. Indeed, there is no alternative to the distortions inherent in projecting, scaling, framing, and coding, as even the three-dimensional graphs designed by skilled cartographers (e.g., of Palestine in Besse \& Tiberghien 2017: 65) can only give the illusion of depth, not actually reproduce it.

Denise Dennerlein (2009: 238), in her narratological analysis of space in fiction, has argued that the most exhaustive descriptions always include Leerstellen (literally "empty places"), which she defines as "missing information about spatial elements of the storyworld." Similarly, theorists of cartography have emphasized that the process of mapping necessarily involves selection, hence 
deletions and omissions. James Corner (1999: 246), for example, has shown that Charles Joseph Minard's celebrated map of Napoleon's Russian campaign is most discriminating; while highly elaborate (it includes no less than six variables), it only depicts "the facts that are relevant to its narrative theme." It would be pointless to go over the maps I am discussing and ask what they have deleted or omitted, on the assumption that they indeed have discarded significant information. We could, at the most, mention with regard to Map 1 that the air force, whose importance in German Blitzkrieg strategy has often been pointed out, is not entitled to icons in the same way as the infantry and panzer divisions are. It is merely listed (as Luftflotte I, II, and III) in the legends that specify the makeup of the three army groups. Whether this graphic demotion means that the cartographer intended to establish a hierarchy between the infantry, the panzer, and the air force divisions, or merely lacked space to represent the air force with an icon, is open to question.

Let us point out, to conclude, that in matters of selection the maps I have examined differ in one respect at least from the graphs of fictional narratives that Moretti and critics in his legacy have drawn: they can be redesigned. Indeed, Moretti (1998: 92) would be unable, on the basis of materials establishing what the character "actually did," to modify, say, the map of Lucien's route on the day of his success in Balzac's Les illusions perdues; the only available information is in the text, which means that it cannot be confirmed or disallowed with the help of external documentary evidence. As historiographic studies, in contrast, are the objects of frequent rewritings, the maps in my corpus could be redrawn: not only because new data could show that they are flawed, but because additional questions could be posed or, more fundamentally, because the temporal distance between the events and the cartographer has increased, providing new perspectives. While Map 2, for instance, accurately describes the initial phase of the conflict, it does not account for - to stay with the problematic of space - the size of the territory the Nazis still had to conquer in order to achieve their goals. As the graphs included in the analysis of the successive versions of Generalplan Ost show (Ingrao 2016: 14-16), the Germans - had they taken Moscow - had yet to march another 600 kilometers to reach the Volga, another 1200 kilometers to get to the Ural Mountains. Map 2 could thus be widened to better reflect, through graphic means, the role of space as an "actant” in the war on the Eastern Front, a role that all studies of the war stress over and over - even though they may not draw on Greimas's (1982: 5) terminology to do so. 


\section{References}

Bakhtin, Mikhail. 1981. The dialogic imagination: Four essays. Trans. Michael Holquist \& Caryl Emerson. Austin: University of Texas Press.

Baroni, Raphaël. 2007. La tension narrative: Suspense, curiosité et surprise. Paris: Seuil. Benjamin, Walter. 1969. Illuminations. Trans. Harry Zohn. New York: Schocken Books.

Bertin, Jacques. 2010. Semiology of graphics: Diagrams, networks, maps. Trans. William J. Berg. Redlands, CA: Esri Press.

Besse, Jean-Marc \& Gilles A. Tiberghien (eds.). 2017. Opérations cartographiques. Arles: Actes Sud.

Bourdieu, Pierre. 1994. Raisons pratiques: Sur la théorie de l'action. Paris: Seuil.

Buchholz, Sabine, and Manfred Jahn. 2005. Space in narrative. In David Herman, Manfred Jahn \& Marie-Laure Ryan (eds.), Routledge encyclopedia of narrative theory, 551-555. London \& New York: Routledge.

Caquard, Sébastien \& Jean-Pierre Fiset. 2014. How can we map stories? A cybercartographic application for narrative cartography. Journal of Maps 10(1). 18-25.

Carrard, Philippe. 2010. The French who fought for Hitler: Memories from the outcasts. New York: Cambridge University Press.

Certeau, Michel de. 1988. The writing of history. Trans. Thomas Conley. New York: Columbia University Press.

Cohn, Dorrit. 1999. The distinction of fiction. Baltimore \& London: Johns Hopkins University Press.

Corner, James. 1999. The agency of mapping: Speculation, critique, and invention. In Denis Cosgrove (ed.), Mapping, 212-252. London: Reaktion Books.

Cosgrove, Denis. 2008. Geography and vision: Seeing, imagining and representing the world. London \& New York: I.B. Tauris.

Danto, Arthur. 1985. Narration and knowledge. New York: Columbia University Press.

Dennerlein, Katrin. 2009. Narratologie des Raumes. Berlin: De Gruyter.

Derrida, Jacques. 1978. Writing and difference. Trans. Alan Bass. Chicago: University of Chicago Press.

Genette, Gérard. 1980. Narrative discourse: An essay in method. Trans. Jane E. Lewin. Ithaca, NY: Cornell University Press.

Genette, Gérard. 1997. Paratexts: Thresholds of interpretation. Trans. Janet E. Lewin. New York: Cambridge University Press.

Greimas, A.J. \& J. Courtès. 1982. Semiotics and language: An analytical dictionary. Trans. Larry Crist et al. Bloomington: Indiana University Press.

Hamon, Philippe. 1982. Un discours contraint. In Gérard Genette \& Tzvetan Todorov (eds.), Littérature et réalité, 119-181. Paris: Seuil.

Harley, John Brian. 2001. The new nature of maps: Essays in the History of Cartography. Baltimore \& London: Johns Hopkins University Press.

Ingrao, Christian. 2016. La promesse de l'est: Espérance nazie et génocide, 1939-1943. Paris: Seuil.

Krah, Hans. 1999. Räume, Grenzen, Grenzenüberschreitungen: Einführende Überlegungen. Ars Semiotica 22(1-2). 3-13.

Lejeune, Philippe. 1989. On autobiography. Trans. Katherine M. Leary. Minneapolis: University of Minnesota Press. 
Monmonier, Mark. 1991. How to lie with maps. Chicago \& London: University of Chicago Press.

Monmonier, Mark. 1993. Mapping it out: Expository cartography for the humanities and social sciences. Chicago \& London: University of Chicago Press.

Moretti, Franco. 1998. Atlas of the European novel, 1800-1900. London \& New York: Verso.

Müller, Rolf-Dieter, and Gerd R. Ueberschär. 2009. Hitler's war in the East: A critical assessment. Trans. Bruce D. Little. New York \& Oxford: Berghahn Books.

O’Neil, Patrick. 2005. Narrative structure. In David Herman, Manfred Jahn \& Marie-Laure Ryan (eds.), The Routledge encyclopedia of narrative theory, 366-370. New York: Routledge.

Palsky, Gilles. 2017. Cartes, temps et récit. In Jean-Marc Besse \& Gilles A. Tiberghien (eds.), Opérations cartographiques, 57-69. Arles: Actes Sud.

Phelan, James. 2007. Experiencing fiction: Judgments, progression, and the rhetorical theory of narrative. Columbus: Ohio State UP.

Pickles, John. 2004. A history of space: Cartographic reason, mapping and the geo-coded world. London \& New York: Routledge.

Prince, Gerald. 2005. Narrativity. In David Herman, Manfred Jahn \& Marie-Laure Ryan (eds.), Routledge encyclopedia of narrative theory, 387-388. New York: Routledge.

Prince, Gerald. 2012. Récit minimal et narrativité. In Sabrinelle Bedrane, Françoise Revaz \& Michel Viegnes (eds.), Le récit minimal, 23-32. Paris: Presses de la Sorbonne Nouvelle.

Rabatel, Alain. 1998. Une histoire du point de vue. Paris: Klinksieck.

Ryan, Marie-Laure, 2016. Maps and narrative. In Marie-Laure Ryan, Kenneth Foote \& Maoz Azaryahu (eds.), Narrating space/Spatializing narrative: Where narrative theory and geography meet, 44-74. Columbus: Ohio State University Press.

Sternberg, Meir. 1978. Expositional modes and temporal ordering in fiction. Baltimore \& London: Johns Hopkins University Press.

Story, Ronald. 2006. Concise historical atlas of World War Two: The geography of conflict. New York \& Oxford: Oxford University Press.

White, Hayden. 1978. The fictions of factual representation. In Tropics of discourse, 121-134. Baltimore \& London: Johns Hopkins University Press.

Wood, Denis \& John Fels. 1993. The power of maps. London: Routledge.

Wood, Denis \& John Fels. 2008. The natures of maps: Cartographic constructions of the natural world. Chicago: University of Chicago Press.

Wood, Denis, John Fels \& John Krygier. 2010. Rethinking the power of maps. New York: The Guilford Press.

Young, Peter (ed.). 1999. Atlas of the Second World War. London: Cassel. 